\title{
Mutants of Saccharomyces cerevisiae Partially Defective in the Last Steps of the Haem Biosynthetic Pathway: Isolation and Genetical Characterization
}

\author{
By ANNA KURLANDZKA AND JOANNA RYTKA* \\ Department of Genetics, Institute of Biochemistry and Biophysics, Polish Academy of Sciences, \\ Rakowiecka 36, 02-532 Warsaw, Poland
}

(Received 31 January 1985; revised 5 June 1985)

\begin{abstract}
A novel method for the isolation of Saccharomyces cerevisiae mutants partially defective in haem synthesis is described. Mutant clones were identified by their fluorescence under UV light due to the accumulation of porphyrins in cells, and by their ability to grow on nonfermentable carbon sources due to their preserved haemoprotein synthesis. Thirteen such mutants were obtained by this procedure. The defects in haem synthesis and accumulation of porphyrins in all the mutants were confirmed by spectrophotometric analysis. Complementation tests with biochemically defined, haem-less strains showed that in seven mutants uroporphyrinogen decarboxylase was affected and that in three mutants the defect concerned ferrochelatase. The defects in the remaining three mutants were not defined.
\end{abstract}

\section{INTRODUCTION}

The sequence of enzymic steps leading to protohaem formation is well established and has been found to be the same in all organisms studied so far (Fig. 1), except for the first step (formation of 5-aminolaevulinic acid), which is different in plants (Labbe-Bois \& Labbe, 1978). However, only fragmentary information is available about the regulation of this pathway, most of it obtained by studies of mammalian porphyrias. These diseases are characterized by an excessive increase in production and excretion of porphyrin and/or its precursors due to partial deficiencies of a specific enzyme. The profile of accumulated and excreted haem precursors indicates the existence of compensatory mechanisms overcoming the enzymic defect, to maintain nearly normal end-product synthesis (see references in Elder, 1978; Doss, 1982).

The availability of haem-deficient mutants enables detailed studies of the mechanism of regulation of this pathway to be made. Since Saccharomyces cerevisiae cells totally deficient in haem synthesis are viable and able to grow on fermentable carbon sources, this yeast provides a unique system for studying this problem. Haem-less mutants of Saccharomyces cerevisiae have been isolated on the basis of respiratory deficiency (see references in Mijake et al., 1972; Woods et al., 1975; Gollub et al., 1977), or lack of catalase activity (Pachecka et al., 1974; Labbe-Bois et al., 1977; Urban-Grimal \& Labbe-Bois, 1981). The mutants isolated by Urban-Grimal and Labbe-Bois have been assigned to seven out of the eight enzymic steps of the haem synthetic pathway (Urban-Grimal \& Labbe-Bois, 1981; Camadro et al., 1982). Biochemical analysis of mutants completely blocked in haem synthesis revealed that deficiency in haem due to a defect in a single enzyme led to changes in activities of other enzymes of the pathway (Biliński et al., 1981 ; Urban-Grimal \& Labbe-Bois, 1981; Camadro et al., 1982; Rytka et al., 1984), indicating the complexity of the regulatory mechanisms that coordinate haem synthesis.

The isolation of a mutant of the obligatory aerobic yeast Saccharomycopsis lipolytica, which overproduced protoporphyrin while maintaining haem synthesis (Bassel et al., 1975) prompted us to undertake a systematic search for Saccharomyces cerevisiae mutants partially defective in, or changed in the regulation of, haem synthesis, in which the defect would be expressed 


\section{Succinyl-CoA $+$ \\ Glycine \\ 5-ALA
synthase hem I}

mitochondrial matrix

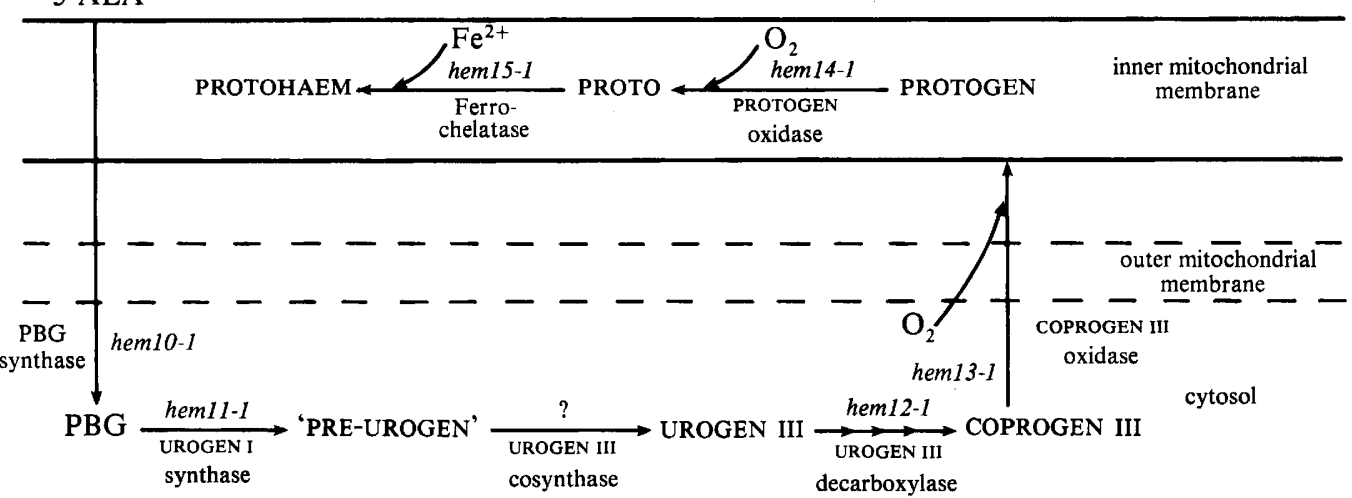

Fig. 1. Scheme of the pathway of protohaem synthesis in Saccharomyces cerevisiae. The scheme is in agreement with data presented by Labbe-Bois et al. (1983). hem-1, and hem 10-1 to heml5-1 are mutations giving a totally haem-deficient phenotype; they have been assigned to successive enzymic steps of the pathway. Intermediates: 5-ALA, 5-aminolaevulinic acid; PBG, porphobilinogen; UROGEN, uroporphyrinogen; COPROGEN, coproporphyrinogen; PROTOGEN, protoporphyrinogen; PROTO, protoporphyrin IX.

phenotypically as accumulation and/or excretion of porphyrin and its precursors with preserved respiration and ability to grow on nonfermentable carbon sources. Because of the fluorescence of porphyrins, it was expected that mutant colonies accumulating haem precursors would fluoresce under UV light. The results described here show that this assumption was justified.

\section{METHODS}

Strains. The haploid Saccharomyces cerevisiae strains used are listed in Tables 1 and 2.

Media and culture conditions. Yeast strains were routinely grown on YPG medium, containing $1 \%(\mathrm{w} / \mathrm{v})$ yeast extract, $2 \%(\mathrm{w} / \mathrm{v})$ bacto-peptone and $2 \%(\mathrm{w} / \mathrm{v})$ glucose, or on YPE medium (glucose replaced by $2 \%, \mathrm{v} / \mathrm{v}$, ethanol). When necessary, media were supplemented with a mixture of Tween 80/Tween $20(4: 1$, final concentration $1 \%$, $\mathrm{v} / \mathrm{v}$ ) and ergosterol $\left(20 \mathrm{mg}^{-1}\right)$ (YPG-TE, YPE-TE). Solid media were prepared by adding $2 \%(\mathrm{w} / \mathrm{v})$ agar.

For analysis of absorption spectra, cells were either grown at $30^{\circ} \mathrm{C}$ in liquid media in a rotatory shaker and harvested at early stationary phase by centrifugation, or grown on plates for $48 \mathrm{~h}$ and scraped off the agar.

Mutagenesis and genetic analysis. One-step standard mutagenesis by ethyl methanesulphonate, methyl methanesulphonate or UV treatment was performed (Fink, 1970). Standard media and procedures were used for crossing, sporulation and tetrad analysis (Mortimer \& Hawthorne, 1969; Fink, 1970).

Spectra of whole cells. Spectrophotometric analysis of cytochrome and tetrapyrrolic pigment content was performed on whole cell pastes at liquid nitrogen temperature with folded Parafilm as a blank. The spectra were recorded on a Specord UV VIS spectrophotometer. Reduction was achieved by endogenous substrates (Rytka et al., 1978).

\section{RESULTS AND DISCUSSION \\ Isolation of mutants}

Porphyrins may be detected directly in biological materials by their characteristic red fluorescence (Falk, 1964). We found that strain B214 of Saccharomycopsis lipolytica, which overproduced protoporphyrin IX (Bassel et al., 1975), strongly fluoresced when colonies were examined under UV at $366 \mathrm{~nm}$. Therefore it seemed possible to select Saccharomyces cerevisiae mutants accumulating porphyrin precursors on the basis of colony fluorescence. 
Table 1. Strains of Saccharomyces cerevisiae used

\begin{tabular}{|c|c|c|}
\hline Designation & Genotype & Source \\
\hline $\begin{array}{l}\text { SP4 } \\
\text { SP20 }\end{array}$ & $\begin{array}{l}\alpha \text { leul arg } 4 \\
\text { a leul adel }\end{array}$ & Biliński et al. (1980) \\
\hline $\begin{array}{l}754 \\
\text { AH22 } \\
\text { AH201 }\end{array}$ & $\begin{array}{l}\text { a leu2-3 leu2-112 } \text { hhis } 3 \text { his } 4 \text { ura3 trpl } \\
\text { a leu2-3 leu2-112 his4-519 canl } \\
\alpha \text { his } 3 \text { ura } 3 \text { trpl }\end{array}$ & $\begin{array}{l}\text { Department of Genetics, Warsaw } \\
\text { University }\end{array}$ \\
\hline DCT $1-3 \mathrm{D}$ & a leul arg 4 cttl -1 & \\
\hline DCT3-4A & a leul arg 4 ctal-1 & \\
\hline DCT17-1C & $\begin{array}{l}\alpha \text { leul leu2-3 leu2-112 ade } 2 \text { his } 4-514 \text { ctt I-I } \\
\text { ctt4-1 ctal-5 }\end{array}$ & This laboratory (unpublished) \\
\hline DCT26-1C & $\alpha$ leul arg 4 ctal-1 & \\
\hline DCT24-8C & a leul his 3 & Our collection \\
\hline G121 & a ura2-3 hem 12-1 rho- & Urban-Grimal \& Labbe-Bois (1981) \\
\hline DSm19-2D & $\alpha$ his4 ade 2 hem $12-1$ & This study, segregant from $\mathrm{G} 121 \times \mathrm{Sm} 4$ \\
\hline G122 & a ura2-35 hem $14-1$ & Camadro et al. (1982) \\
\hline DSm66-2B & $\alpha$ trpl hem $14-1$ & This study, segregant from $\mathrm{G} 122 \times \mathrm{AH} 201$ \\
\hline $\mathrm{G} 214$ & $\alpha$ his4 hem15-1 & Urban-Grimal \& Labbe-Bois (1981) \\
\hline GG214-4D & a leul hem15-1 & R. Labbe-Bois, unpublished \\
\hline G216 & $\alpha$ his4 hem13-1 & Urban-Grimal \& Labbe-Bois (1981) \\
\hline $\begin{array}{l}\text { DSm65-2C } \\
\text { cat9-4C }\end{array}$ & $\begin{array}{l}\text { a leu2 } \mathrm{His}^{-} \text {ura3 hem13-1 } \\
\alpha \text { leul } \mathrm{Met}^{-} \text {rho }{ }^{\circ} \text { hem } 12-11\end{array}$ & $\begin{array}{l}\text { This study, segregant from G216 × } 754 \\
\text { Pachecka et al. }(1974)\end{array}$ \\
\hline DSm3-2A & a $\mathrm{Leu}^{-} \mathrm{His}^{-}$ura3 hemI2-2 & This study, segregant from $\operatorname{Sm} 1 \times \operatorname{Sm} 7$ \\
\hline DSm2-3D & a Leu- $\mathrm{Ade}^{-}$hem12-10 & This study, segregant from $\operatorname{Sm} 6 \times \mathrm{SP} 20$ \\
\hline DSml-2C & a leul his4 $\mathrm{Ade}^{-}$hem15-2 & This study, segregant from $\mathrm{Sm} 4 \times \mathrm{SP} 20$ \\
\hline DSm6-4D & $\alpha$ leul arg 4 heml5-3 & This study, segregant from $\mathrm{Sm} 12 \times \mathrm{Sm} 1$ \\
\hline
\end{tabular}

\section{Table 2. Genotypic characteristics of mutants isolated}

Ten of the Sm mutants have been assigned to known HEM loci on the basis of absence of complementation with defined hem $12-1$ and hem 15-1 mutant strains (Urban-Grimal \& Labbe-Bois, 1981); the numbers of mutated alleles are also given. The genetic lesions in strains Sm14, Sm20 and Sm32 have not been determined.

\begin{tabular}{|c|c|c|}
\hline Designation & Parental strain & Genotype of mutant \\
\hline Sml & SP4 & $\alpha$ leul arg4 hem12-2 (Rytka et al., 1984) \\
\hline $\mathrm{Sm} 2$ & SP4 & a leul arg4 hem12-3 (Rytka et al., 1984) \\
\hline $\mathrm{Sm} 3$ & SP4 & a leul arg4 hem12-4 (Rytka et al., 1984) \\
\hline Sm4 & DCT17-1C & $\alpha$ leul leu2-3 leu2-112 ade2 his4-514 cttl-1 ctt4-1 ctal-5 hemls-2 \\
\hline Sm6 & DCT $17-1 \mathrm{C}$ & a leul leu2-3 leu2-112 ade2 his4-514 cttl-1 ctt4-1 ctal-5 heml2-10 \\
\hline Sm7 & 754 & a leu2-3 leu2-112 $\Delta$ his 3 his4 ura3 trpl hem12-I2 \\
\hline $\mathrm{Sm} 12$ & DCT1-3D & a leul arg 4 ctt $1-1$ hem $15-3$ \\
\hline $\operatorname{Sm} 39$ & DCT26-1C & $\alpha$ leul arg4 ctal-1 hem12-5 \\
\hline Sm40 & DCT26-1C & $\alpha$ leul arg4 ctal-1 hem12-6 \\
\hline Sm41 & DCT3-4A & a leul arg 4 ctal-1 hem15-4 \\
\hline $\mathrm{Sm} 14$ & DCT24-8C & a leul his $3 \mathrm{Hem}^{-}$ \\
\hline $\operatorname{Sm} 20$ & DCT24-8C & a leul his $3 \mathrm{Hem}^{-}$ \\
\hline $\operatorname{Sm} 32$ & DCT24-8C & a leul his $3 \mathrm{Hem}^{-}$ \\
\hline
\end{tabular}

Since the aim of this work was the isolation of mutants partially defective in haem formation, mutants of interest would be able to respire, due to preserved haemoprotein synthesis, and consequently would grow on nonfermentable carbon sources. Cells grown in liquid YPE to the stationary phase were mutated and plated on solid YPE medium (10000 cells per plate, $1 \%$ survival). After 4-5 d incubation at $30^{\circ} \mathrm{C}$, well-grown colonies were tested for red fluorescence under UV light at $366 \mathrm{~nm}$. The fluorescing clones were purified by restreaking and again examined under UV. For further analysis, clones which continued to fluoresce after at least four subclonings were isolated. By this procedure 13 fluorescing mutants, named $\mathrm{Sm}$, were isolated out of $1.8 \times 10^{5}$ colonies tested in eight independent mutageneses. The parent strains and $\mathrm{Sm}$ mutants are listed in Table 2. 




Fig. 2. Low-temperature absorption spectra of whole cells of Sm mutants. $(a, b)$ Wild-type strain SP4 (WT), mutants Sm1, Sm2, Sm3, Sm6, Sm7, Sm39 and Sm40, and the hem12-1 mutant G121 allelic to them. (c) Wild-type strain, mutants $\mathrm{Sm} 4, \mathrm{Sm} 12$ and $\mathrm{Sm} 41$, and the hem15-1 mutant G214 allelic to them. (d) Wild-type strain and mutants $\mathrm{Sm} 14, \mathrm{Sm} 20$ and $\mathrm{Sm} 32$.

\section{Spectrophotometric analysis of whole cells}

Spectrophotometric analysis of the cytochrome and tetrapyrrolic pigment content of the mutant cells revealed the accumulation of porphyrin precursors. The whole-cell spectra of each of the mutants (Fig. 2) show the accumulation of porphyrins or Zn-porphyrins characterized by absorption peaks at about 540-545, 570-575 and $630 \mathrm{~nm}$ (Chaix \& Labbe, 1965; Pretlow \& Sherman, 1967; Labbe-Bois et al., 1977). In some mutants the vast accumulation of porphyrins masked the cytochrome peaks. The accumulation of a mixture of free and $\mathrm{Zn}$-chelated porphyrins was described by Urban-Grimal and Labbe-Bois (1981) for mutants hem12-1, hem14-1 and hem15-1, blocked in the fifth, seventh and eighth step of haem synthesis, respectively (Fig. 1). Pigments absorbing at $535 \mathrm{~nm}$ and $575 \mathrm{~nm}$ were also observed in whole-cell spectra of the haem-deficient mutant $\mathrm{H} 11$, deficient in coproporphyrinogen oxidase activity (the sixth step of the haem biosynthetic pathway) (Biliński et al., 1981).

\section{Segregation of Sm phenotype}

Sm mutants were crossed with standard strains of opposite mating type (SP20, AH22, AH201). All the diploids isolated failed to fluoresce under UV light and gave normal, wild-type cytochrome spectra, showing that all the mutations were recessive. Tetrad analysis of the crosses was carried out. The spore colonies were tested for mating type, auxotrophic markers and fluorescence. Segregation of the mutant to the wild-type phenotype was $2: 2$, indicating that the observed porphyrin accumulation was under control of a single, nuclear gene. Although a clear $2: 2$ segregation was observed when the cytochrome spectra of spore clones were analysed, some of the Sm segregants contained less or more pigment than the original mutant. The same effect was observed for the pop $p_{1}$ mutant of Saccharomyces cerevisiae described by Pretlow \& Sherman (1967) and for the pop $p_{1}$ mutant of Saccharomycopsis lipolytica (Bassel et al., 1975). This phenomenon was especially pronounced in some spore derivatives of crosses of $\operatorname{Sm} 14, \operatorname{Sm} 20$, $\mathrm{Sm} 32$ with the standard strain. It should be noted that the viability of spores was very low and only a few tetrads were analysed. 


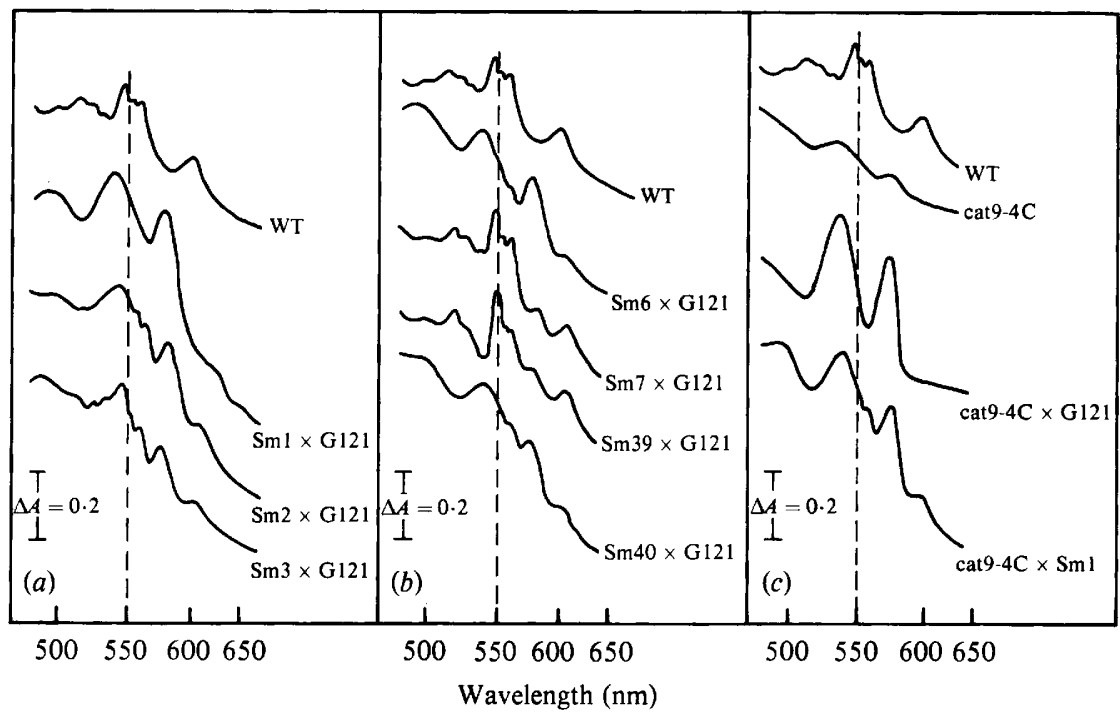

Fig. 3. Low-temperature absorption spectra of whole cells of the diploids derived from crosses between the hem12-1 tester strain G121 and mutants allelic to it. WT, wild-type strain SP4.

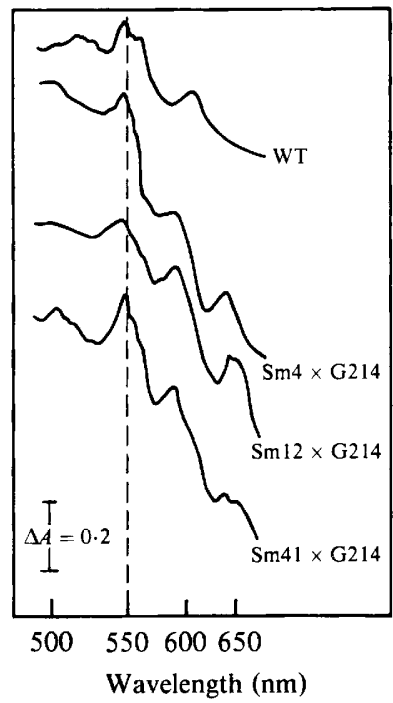

Fig. 4. Low-temperature absorption spectra of whole cells of the diploids derived from crosses between the hem15-I tester strain G214 and mutants allelic to it. WT, wild-type (strain SP4).

\section{Complementation tests}

As mentioned above, mutants completely blocked in seven steps of haem synthesis were isolated by Urban-Grimal \& Labbe-Bois (1981) (Fig. 1). In order to define in which of the steps of haem biosynthesis the Sm mutants were defective, complementation tests were performed with the set of $\mathrm{Hem}^{-}$mutants with defined lesions. Since porphyrins are formed by enzymic addition of four porphobilinogens, we chose for the complementation the strains defective in steps following the block in uroporphyrinogen I synthase, i.e. those deficient in uroporphyrinogen decarboxylase (hem12-1), coproporphyrinogen III oxidase (hem13-1), protoporphyrinogen oxidase (hem14-1) and ferrochelatase (hem15-1). The diploids derived from crosses of Sm mutants with test strains were examined for fluorescence and by running low-temperature spectra of whole cells. The results of complementation analysis are reported in Table 3, and Figs $3(a, b)$ and 4 show the spectra of cells of noncomplementing diploids as compared with spectra 


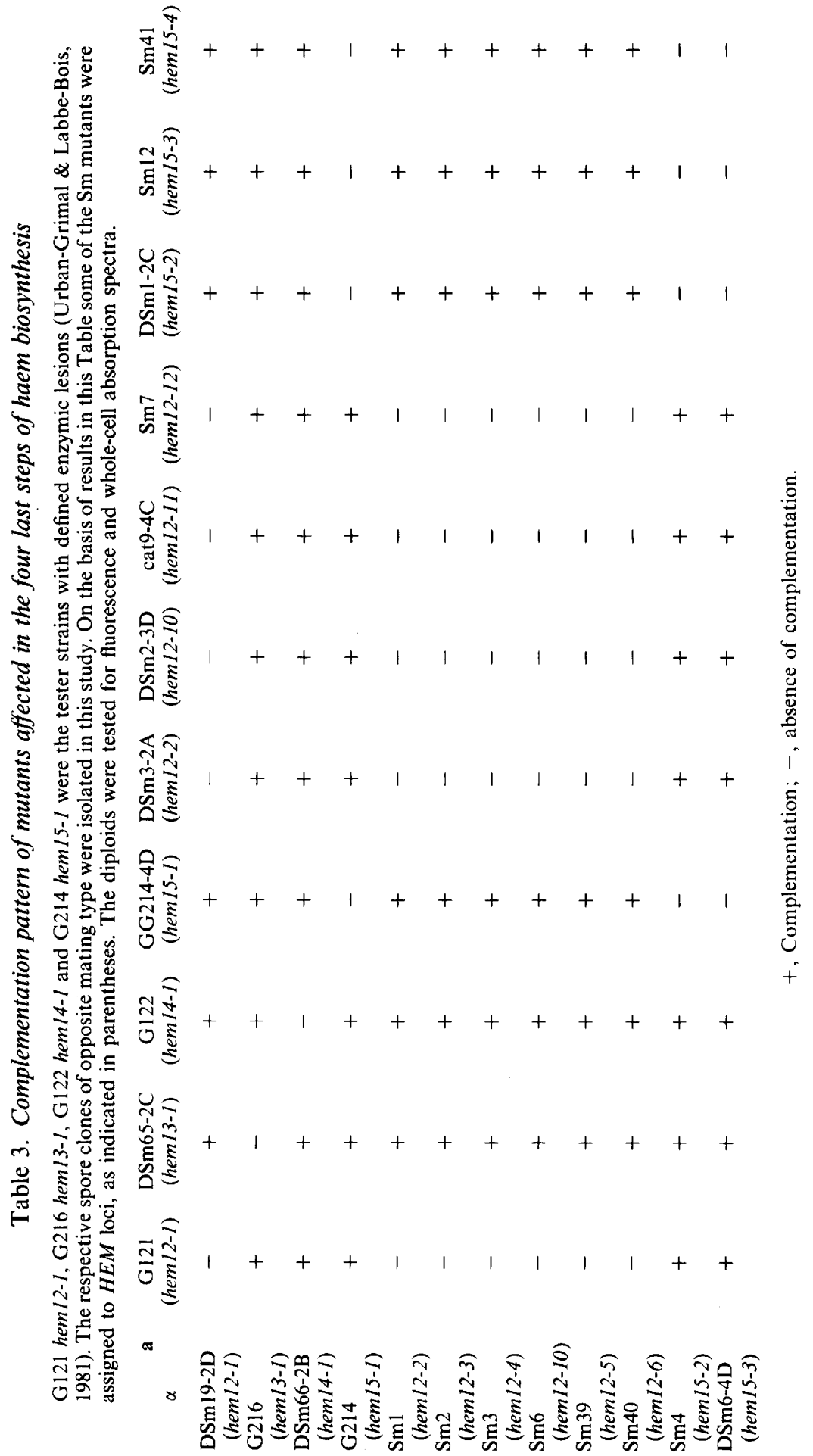


of the parental haem-deficient strains. It appeared that mutants $\mathrm{Sml}, 2,3,6,7,39$ and 40 belonged to the same complementation group and did not complement hem12-1 (G121), totally deficient in uroporphyrinogen decarboxylase, whereas Sm4, 12 and 41 did not complement the hem15-1 (G214) mutant lacking ferrochelatase activity. In all cases the diploids exhibited the phenotype of the Sm parent in that they grew on ethanol and gave absorption spectra characteristic for strains partially defective in haem synthesis. The mutations leading to porphyrin formation in strains $\mathrm{Sm} 14, \mathrm{Sm} 20, \mathrm{Sm} 32$ could not be assigned to any known $H E M$ locus, since they complemented all the test $\mathrm{Hem}^{-}$mutants; they also complemented each other. It is possible that these three mutants have defects in gene(s) involved in regulation of haem synthesis, but to test this possibility a detailed genetic analysis is necessary.

\section{Mutants in the HEM12 locus}

Although mutants $\mathrm{Sm} 1, \mathrm{Sm} 2, \mathrm{Sm} 3, \mathrm{Sm} 6, \mathrm{Sm} 7, \mathrm{Sm} 39$ and $\mathrm{Sm} 40$ belonged to the same complementation group, the absorption spectra of whole cell preparations were not identical (Fig. $2 a, b$ ). The most pronounced accumulation of pigments absorbing at 530-535 nm and 570$575 \mathrm{~nm}$ was observed for strain $\mathrm{Sm} 1$. On the other hand, strain Sm7 accumulated less $\mathrm{Zn}$ porphyrins than other mutants of the same group. The same phenomenon was observed in a diploid resulting from a cross of strain $\mathrm{Sm} 7$ with strain G121, bearing the hem12-1 mutation (Fig. $3 b$ ). However, the diploids resulting from crosses of $\mathrm{Sm} 7$ with hem13-1, hem 14-1 and hem 15-1 mutants did not show a Zn-porphyrin absorption band at about $570 \mathrm{~nm}$. Both $\mathrm{Sm} 7$ haploid and diploid $\operatorname{Sm} 7 \times$ G121 strongly fluoresced under UV light; therefore we assigned $\mathrm{Sm} 7$ to the hem 12 complementation group.

We have also analysed the previously isolated cat 9 mutant for which no clear enzymic lesion was found (Labbe-Bois et al., 1977). As is shown in Fig. 3(c), the cat9 mutant appeared to be allelic to G121 and Sml, indicating that the primary defect in cat9 is in uroporphyrinogen decarboxylase.

Detailed biochemical analysis of strain Sm1 (Rytka et al., 1984) proved that its mutation caused a defect in uroporphyrinogen decarboxylase, resulting in a $70-80 \%$ decrease of enzyme activity in cell-free extracts and alteration of the rates of the different decarboxylation steps. It has been shown that the biochemical characteristics of mutant $\mathrm{Sm} 1$ were very similar to those known for human porphyria cutanea tarda, which is characterized by a decreased level of uroporphyrinogen decarboxylase (Sassa \& Kappas, 1981). However, the molecular nature of that defect is not yet known.

Since the spectra of the hem 12 mutants described above are different, we can expect that they carry different defects in uroporphyringogen decarboxylase. Detailed biochemical analysis of the porphyrins accumulated and of the enzyme activity should give some insight into the functioning of uroporphyrinogen decarboxylase, especially concerning the number of catalytic sites.

\section{Mutants in the HEM15 locus}

The phenotype of the Sm mutants allelic to hem15-1 (Sm4, Sm12 and Sm14) depended on the presence of Tween in the medium. Cells grown on YPG, YPE or minimal medium accumulated vast amounts of porphyrins, whose absorption peaks overlapped the cytochrome peaks in the low temperature spectra (Fig. $2 c$ ). These porphyrins are characterized by absorption peaks near $575 \mathrm{~nm}$ and $630 \mathrm{~nm}$ or near $585 \mathrm{~nm}$ and $645 \mathrm{~nm}$ which are due to protoporphyrin monomer or aggregated protoporphyrin, respectively. However, after growth in media containing the standard mixture of Tween 80 and Tween 20 , the mutant cells still fluoresced under UV light but their absorption spectra were much the same as those of the wild-type (Fig. 5). In strains Sm4 and $\mathrm{Sm} 12$ the small peak at $630 \mathrm{~nm}$, corresponding to protoporphyrin monomers, was still observed, but in strain Sm4l even that peak disappeared. When the cells were grown on solid minimal medium supplemented with Tween, the characteristic red fluorescence of the medium surrounding the colony was observed. Therefore in the presence of Tween the cells excreted the porphyrins into the medium. Addition of other detergents such as Brij-35 and Triton X-100 to the medium also caused excretion of the protoporphyrin by mutant cells. This effect of 


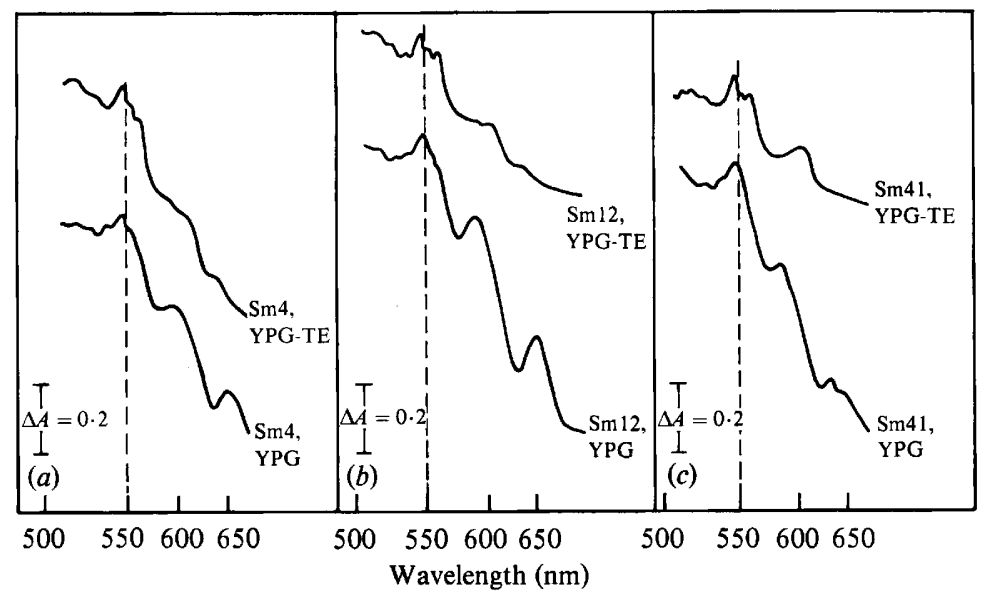

Fig. 5. Low-temperature absorption spectra of whole cells of mutants $\operatorname{Sm} 4(a), \operatorname{Sm} 12(b)$ and $\operatorname{Sm} 41(c)$ grown on YPG or YPG-TE medium.

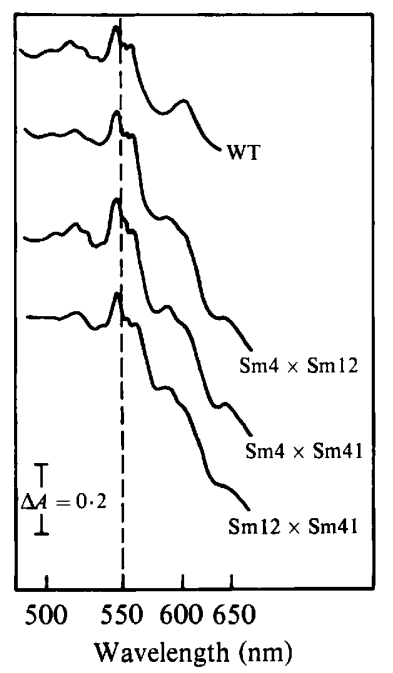

Fig. 6. Low-temperature absorption spectra of whole cells of the diploids derived from crosses between mutants $\mathrm{Sm} 4 \times \mathrm{Sm} 12, \mathrm{Sm} 4 \times \mathrm{Sm} 41$ and $\mathrm{Sm} 12 \times \mathrm{Sm} 41$.

detergents was not observed with the hem 15-1 strain G214, which helped us to differentiate the segregation of Sm and G214 phenotypes in tetrad analysis. A similar phenomenon has been described by Bassel et al. (1975) in the pop $p_{1}$ mutant of Saccaromycopsis lipolytica that accumulated protoporphyrin IX and excreted it when grown on media containing detergents such as Tween 40 or Tergitol.

For more detailed genetic analysis the diploid derivatives of crosses $\mathrm{Sm} 12 \times \mathrm{Sm} 4$, $\mathrm{Sm} 4 \times \mathrm{Sm} 41$ and $\mathrm{Sm} 12 \times \mathrm{Sm} 41$ were analysed. The mutants did not complement. The diploids fluoresced and their low-temperature spectra showed the accumulation of protoporphyrin (Fig. 6). The diploids sporulated but the viability of the spores was extremely poor. From about 100 tetrads dissected, only 4 complete tetrads were obtained; all showed the parental ditype of segregation for porphyrin accumulation.

The diploid derivatives of crosses $\mathrm{Sm} 12 \times \mathrm{G} 214$ and $\mathrm{Sm} 41 \times \mathrm{G} 214$ sporulated and germinated fairly well. Tetrad analysis of these diploids was carried out (Table 4). The spore colonies were tested for segregation of mating type, auxotrophic markers and mutant phenotype defined by fluorescence, and for protoporphyrin accumulation by means of absorption spectra. 
Table 4. Segregation pattern of characters associated with allelic mutations in the HEM15 locus

Tetrad analysis was performed on 28 tetrads derived from diploids from the crosses Sm $12 \times$ G214 (18 tetrads) and Sm41 $\times$ G214 (10 tetrads). Catalase activity was detected by the colony test (Pachecka $e t$ al., 1974): detectable activity indicated at least residual haem synthesis. The inability to grow on ethanol (YPE medium) was characteristic of the G214 parent.

Tetrad segregation pattern

$4: 0$
$3: 1$
$2: 2$
$1: 3$
$0: 4$

$3: 1$

$2: 2$

$0: 4$

\begin{tabular}{|c|}
\hline $\begin{array}{l}\text { Fluorescence } \\
\qquad(+:-)\end{array}$ \\
\hline 28 \\
\hline 0 \\
\hline 0 \\
\hline 0 \\
\hline 0 \\
\hline
\end{tabular}

Number of tetrads segregating for:

To distinguish the phenotype of the G214 parent the inability to grown on ethanol, and catalase activity (an indicator of haem synthesis), were also analysed. In all the tetrads fluorescence and absorption spectra showed the parental ditype of segregation, indicating that mutants $\operatorname{Sm} 12$ and $\mathrm{Sm} 41$ were allelic with G214. However, two other phenotypic characteristics of strain G214 did not segregate $2: 2$ in all tetrads analysed. In five segregants the restoration of haem synthesis (presence of active catalase) was not correlated with the ability to grow on nonfermentable carbon sources. Moreover, three segregants required Tween and ergosterol for growth, which was not the case for the parental strains. These irregularities in segregation disagree with the predicted segregation of two mutated alleles of the same gene. We expected that the traits resulting from the complete block of haem synthesis in strain G214 would segregate 2:2. The genetic data might indicate that the lack of ferrochelatase activity in strain G214 resulted from two mutations: one, hem 15-1, affecting the structural gene of ferrochelatase and another affecting the expression of this mutation. However, simultaneously we have observed a high frequency of 'partial reversion' in strain G214. The reverted colonies accumulated protoporphyrin and did not grow on ethanol but they synthesized haem, as judged by the restoration of catalase activity.

To interpret these results one has to take into account the multiplicity of factors which could interfere with the last step of haem synthesis. The ferrochelatase essentially catalyses the insertion of $\mathrm{Fe}^{2+}$ into protoporphyrin IX. It is a membrane-bound enzyme localized in the inner mitochondrial membrane so its activity is dependent on the presence of fatty acids and/or phospholipids. It requires for normal functioning an adequate supply of protoporphyrin, and normal metabolism of $\mathrm{Fe}^{2+}$. On the other hand, the accessibility of protohaem for metabolic functions may modify the phenotype due to haem deficiency (Camadro \& Labbe, 1982; Taketani \& Tokunaga, 1981, 1984; Labbe-Bois et al., 1983). Therefore our results may indicate that depending on the physiological conditions, the same mutation can be expressed differently, reflecting the complexity of functioning of ferrochelatase.

This work was supported by the Polish Academy of Sciences under Project 09.7.2, and forms a part of the PhD thesis of Anna Kurlandzka.

The authors are deeply grateful to Dr Rosine Labbe-Bois for providing test strains and for comments on the manuscript.

\section{REFERENCES}

Bassel, J., HAMbright, P., Mortimer, R. \& BeARden, J. A. (1975). Mutant of the yeast Saccharomycopsis lipolytica that accumulates and excretes protoporphyrin IX. Journal of Bacteriology 123, 118122.

BILIŃSKI, T., LITWIŃSKA, J., SLedzIEwSKI, A. \& RYTKA, J. (1980). Genetic analysis of pleiotropic mutants affected in the response to glucose repres- sion and anoxia. Acta microbiologica polonica 29, 199-212.

BILIŃSKI, T., LITWIŃSKA, J., ŁUKASZKIEWICZ, J., RytKa, J., Simon, M. \& LabBe-BoIs, R. (1981). Characterization of two mutant strains of Saccharomyces cerevisiae deficient in coproporphyrinogen III oxidase activity. Journal of General Microbiology 122, $79-87$. 
Camadro, J.-M. \& LabBe, P. (1982). Kinetic studies of ferrochelatase in yeast. Zinc or iron as competing substrates. Biochimica et biophysica acta 707, 280288.

Camadro, J.-M., Urban-Grimal, D. \& Labbe, P. (1982). A new assay for protoporphyrinogen oxidase - evidence for a total deficiency in that activity in a heme-less mutant of Saccharomyces cerevisiae. Biochemical and Biophysical Research Communications 106, 724-730.

ChaIX, P. \& LABBe, P. (1965). A propos de l'interprétation du spectra d'absorption de cellules de levures récoltées à la fin ou après la phase exponentielle de leur croissance anaérobie. In Mecanismes de Régulation des Activités Cellulaires chez les Microorganismes (Colloque International, Marseille, 1963), pp. 481490. Paris: Centre National de la Recherche Scientifique.

Doss, M. O. (1982). Hepatic porphyrias: pathobiochemical, diagnostic and therapeutic implications. In Progress in Liver Diseases, vol. VII, pp. 573-597. Edited by H. Popper \& F. Schaffner. New York: Grune \& Stratton.

EldER, G. H. (1978). Porphyria caused by hexachlorobenzene and other polyhalogenated aromatic hydrocarbons. In Heme and Hemoproteins, pp. 157-200. Edited by F. De Matteis \& W. N. Aldrige. Berlin, Heidelberg \& New York: Springer Verlag.

FALK, J. E. (1964). Porphyrines and Metalloporphyrines (BBA Library, vol. 2). Amsterdam, London \& New York: Elsevier.

FINK, G. R. (1970). The biochemical genetics of yeast. Methods in Enzymology 17A, 59-78.

Gollub, E. G., Liu, K., Dayan, J., Adlersberg, M. \& SPRINSON, D. B. (1977). Yeast mutants deficient in heme biosynthesis and a heme mutant additionally blocked in cyclization of 2,3-oxidosqualene. Journal of Biological Chemistry 252, 2846-2854.

Labbe-BoIS, R. \& LABBe, P. (1978). Protohaem synthesis in Saccharomyces cerevisiae. In Biochemistry and Genetics of Yeasts, pp. 97-117. Edited by M. Bacilla, B. L. Horecker \& A. O. M. Stoppani. New York \& London: Academic Press.

LabBe-BoIs, R., RYTKa, J., LitwińsKa J. \& BilińsKi, T. (1977). Analysis of heme biosynthesis in catalase and cytochrome deficient mutants. Molecular and General Genetics 156, 177-183.

labbe-Bois, R., Urban-Grimal, D., Volland, C., Camadro, J. \& Dehoux, P. (1983). A bout the regulation of protoheme synthesis in the yeast
Saccharomyces cerevisiae. In Mitochondria 1983, pp. 523-534. Edited by R. J. Schweyen, K. Wolf \& F. Kaudewitz. Berlin \& New York: Walter de Gruyter.

Mijake, S., Iwamoto, Y., Nago, M., Sugimura, T. \& OHSUMi, M. (1972). Phenotype of a temperaturesensitive respiration-deficient (cyt) mutant of yeast. Journal of Bacteriology 109, 409-415.

Mortimer, R. K. \& HAWTHORNE, D. C. (1969). Yeast genetics. In The Yeasts, vol. I, pp. 385-460. Edited by A. H. Rose \& J. S. Harrison. London \& New York: Academic Press.

PaChecka, J., LitwińsKa, J. \& Biliński, T. (1974). Hemoprotein formation in yeast. I. Isolation of catalase- and cytochrome-deficient mutants. Molecular and General Genetics 134, 299-305.

Pretlow, T. P. \& Sherman, F. (1967). Porphyrins and zinc-porphyrins in normal and mutant strains of yeast. Biochimica et biophysica acta 148, 629-644.

RytKa, J., Sledziewski, A., LuKaszkiewicz, J. \& BILIŃSKI, T. (1978). Haemoprotein formation in yeast. III. The role of carbon catabolite repression in the regulation of catalase $\mathrm{A}$ and $\mathrm{T}$ formation. Molecular and General Genetics 160, 51-57.

RYTKA, J., BILIŃSKI, T. \& LABBE-BoIS, R. (1984). Modified uroporphyrinogen decarboxylase activity in a yeast mutant which mimics porphyria cutanea tarda. Biochemical Journal 218, 405-413.

SASSA, S. \& KAPPAS, A. (1981). Genetic, metabolic and biochemical aspects of the porphyrias. Advances in Human Genetics 11, 121-231.

TAKeTANI, S. \& Tokunaga, R. (1981). Rat liver ferrochelatase. Purification, properties and stimulation by fatty acids. Journal of Biological Chemistry 256, 12748-12753.

Taketani, S. \& Tokunaga, R. (1984). Non-enzymatic heme formation in the presence of fatty acids and thiol reductants. Biochimica et biophysica acta 798, 226-230.

Urban-Grimal, D. \& LabBe-Bois, R. (1981). Genetic and biochemical characterization of mutants of Saccharomyces cerevisiae blocked in six different steps of heme biosynthesis. Molecular and General Genetics 183, 85-92.

Woods, R. A., SANDERS, H. K., Briquet, M., Foury, F., Drysdale, B. E. \& Matoon, J. R. (1975). Regulation of mitochondrial biogenesis: enzymatic changes in cytochrome-deficient yeast mutants requiring $\delta$-aminolevulinic acid. Journal of Biological Chemistry 250, 9090-9098. 